\title{
EFFECT OF NUTRIENT SOLUTION, EFFECTIVE MICROORGANISMS (EM-A), AND ASSIMILATION ILLUMINATION OF PLANTS ON THE INDUCTION OF THE GROWTH OF LETTUCE (Lactuca sativa L.) IN HYDROPONIC CULTIVATION
}

\author{
Tomasz Kleiber $^{{ }^{*}}$, Justyna Starzyk ${ }^{2}$, Maciej Bosiacki ${ }^{1}$ \\ ${ }^{1}$ Department of Plant Nutrition, Poznan University of Life Sciences, Zgorzelecka 4, 60-199 Poznań, Poland \\ ${ }^{2}$ Department of General and Environmental Microbiology, Poznan University of Life Sciences \\ Szydłowska 50, 60-656 Poznań, Poland \\ *e-mail: tkleiber@up.poznan.pl
}

Received: 13.08.2012

\section{Abstract}

The main aim of the present study was to evaluate the influence of the chemical composition of a nutrient solution (NS I, NS II), seed inoculation with Effective Microorganisms (EM), and assimilation illumination (AI) of plants on the growth, development and nutritional status of lettuce (Lactuca sativa L.) in hydroponic cultivation and microbiological changes in the medium. The measurements were as follows: quantity of leaves per plant (LQ), surface area of the biggest leaves of plants (SBL), relative chlorophyll content (SPAD units), total fresh weight (TFW), total dry weight (TDW), percentage $(\%)$ of dry matter (\% DM), chemical composition of leaves, nutrient uptake $(\mathrm{N}, \mathrm{P}, \mathrm{K}, \mathrm{Ca}, \mathrm{Mg}, \mathrm{Na})$ of the aboveground parts of the plant. It was shown that the simultaneous inoculation of seeds with EM and application of NS II had an effect on improving seed germination $\left(1^{\text {st }}-5^{\text {th }}\right.$ day after sowing), but a significantly positive influence of NS I on seed germination was found from the $5^{\text {th }}$ to $9^{\text {th }}$ day. The application of NS II and EM-A had a positive influence on the development of leaves on the plant. The chemical composition of the nutrient solution was found to have a significant effect on the biometrical parameters of plants. The use of supplemental lighting in cultivation of lettuce affected positively both the growth and development of plants. The chemical composition of the nutrient solution significantly modified the macronutrient nutrition status of plants, while the illumination of plants only in case of phosphorus - but at the same time it had a significant influence on the uptake of all nutrients by the plant. The influence of EM was not proved. The microbiological analysis showed a significant influence of the chemical composition of nutrient solutions on the changes in the numbers of the analyzed groups of microorganisms, showing an increase in their numbers in nutrient solutions with higher contents of chemical elements. However, there were no signi- ficant changes in the number of microorganisms relative to the treatment with assimilation illumination and to that of seed inoculation with EM solutions.

Key words: Lactuca sativa L., Effective Microorganisms, assimilation illumination, plant nutritional status, growth, yielding

\section{INTRODUCTION}

Fresh vegetables enjoy great popularity among consumers, especially during the winter period. An important vegetable that is included in this group is lettuce - but its biological values depend significantly on growth conditions (B r u n s g a a r d et al. 1994). However, the winter period is not favorable for plant cultivation because of insufficient sunlight and the lack of adequate illumination (K l e i b e r et al. 2009). The lack of sunlight is usually the most important factor that determines plant growth and this is the reason why - especially in December and January (in the central part of Europe) - it is advised to use illumination in growing lettuce (A d a micki et al. 2005). Additionally, in traditional lettuce cultivation in soil there is possibility of the uptake of heavy metals and their accumulation in leaves (B o s i a c ki and Ty k sińs ki, 2009), so the use of a closed hydroponic system with a nutrient solution based on very good quality fertilizers (without any ballast ion or heavy metals) protects plants against the above-mentioned heavy metal accumulation. 
Among the factors modifying yielding and the nutritional status of plants, at the same time, their nutritive and biological value, are as follows, among others: application of fertilizers - both in traditional and hydroponic cultivation (Brunsgaard et al. 1994; Kozik and Ruprik, 2000; Karimaei et al. 2004; J a r o s z and D z i d a, 2006), lighting conditions (R o że k et al. 1989; M y c zkowski et al. 1990; K l e i b e r et al. 2009), and also the application of useful microorganisms ( $\mathrm{Li}$ and $\mathrm{Zhang}, 2000$; Abdelaziz and Pokluda, 2009; Górski and K le i b e r, 2010; Fr ą s z c z a k et al. 2012). Particularly interesting is the pressure from a part of consumers to apply microorganisms and to reduce the quantity of chemical components used in foodstuffs (B a 11, 1998; A mjadi and Hussain, 2005). Among the group of microorganisms that could be used in hydroponic cultivation are the following, among others: nitrogen-fixing bacteria Azotobacter and Azospirillum (Abdelaziz and Pokluda, 2009) as well as Effective Microorganisms (EM), being a marketing mixture of lactic acid bacteria, photosynthetic bacteria, yeast and actinomyces (H i g a, 1994; H i g a, 1996; Higa, 1998; Daly and Stewart, 1999).

It has been confirmed that microorganisms possess the ability to fix atmospheric nitrogen and also to produce growth substances, which enables better development and better branching of the root system, and by so doing, helps in the rationalization of water management and also in the uptake of mineral salts by plants (K r ó 1, 2006). The symbiosis of plants with microorganisms is conditional on different physical and chemical factors (W a ld rop et al. 2000; K ou rte v et al. 2002; B o 1 et al. 2003).

The main aim of the present study was to determine the influence of selected factors: chemical composition of a nutrient solution, seed inoculation with EM, and assimilation illumination, on the growth, development and nutritional status of lettuce grown in rockwool in a hydroponic system as well as on microbiological changes in the medium.

\section{MATERIALS AND METHODS}

A growing experiment was carried out in a special greenhouse located within the area of the Experimental Station of the Faculty of Horticulture and Landscape Architecture of the University of Life Sciences in Poznan. The greenhouse was equipped with high quality equipment: climate control, shading and energy-saving curtain systems and an assimilation illumination system. It tested the influence of the chemical composition of a nutrient solution, seed inoculation with Effective Microorganisms (EM), and assimilation illumination of plants on the growth and development of lettuce grown in a hydroponic system in rockwool during the period characterized by reduced light intensity (January - March). The experiment was established using a randomized complete block design in seven replications (one replication was 1 plant) and the lettuce (Lactuca sativa L.) cultivar 'Clotilde' (from ISI SEMENTI, Italy), in which one plant grew in a separate polyethylene $3.45 \mathrm{dm}^{3}$ container.

\section{Chemical composition of the nutrient solution.}

Water used to prepare the nutrient solution for fertigation was characterized by the following nutrient content (in mmol $\times \mathrm{dm}^{-3}$ ): $\mathrm{N}$-ammonium $\left(\mathrm{N}-\mathrm{NH}_{4}\right)$ traces (tr.), nitrogen $(\mathrm{N})$-nitrate $\left(\mathrm{N}-\mathrm{NO}_{3}\right) \quad 0.26$, phosphorus $\left(\mathrm{P}_{-} \mathrm{PO}_{4}\right)$ 0.01, potassium $(\mathrm{K})$ 0.05, calcium $(\mathrm{Ca})$ 1.43, magnesium $(\mathrm{Mg})$ 0.55, sulfur $(\mathrm{S})$-sulfate $\left(\mathrm{SO}_{4}\right)$ 1.82, (in $\left.\mu \mathrm{mol} \times \mathrm{dm}^{-3}\right)$ : iron $(\mathrm{Fe}) 1.43$, manganese $(\mathrm{Mn}) 1.47$, zinc $(\mathrm{Zn})$ 15.2, copper $(\mathrm{Cu})$ tr., boron $(\mathrm{B}) 1.02, \mathrm{pH}$ 7.00 , electrical conductivity (EC) $0.74 \mathrm{mS} \times \mathrm{cm}^{-1}$. Two nutrient solutions with the following chemical composition were used in the experiment: NS I: (in $\mathrm{mmol} \times$ $\left.\mathrm{dm}^{-3}\right) \mathrm{N}-\mathrm{NH}_{4}>0.7, \mathrm{~N}^{-N_{3}}$ 6.1, P 2.75, K 5.24, Ca 1.7, $\mathrm{Mg} \mathrm{1.3,} \mathrm{S}^{-\mathrm{SO}_{4}} 2.1$, (in $\mu \mathrm{mol} \times \mathrm{dm}^{-3}$ ): $\mathrm{Fe} 15, \mathrm{Mn} 30$, $\mathrm{Zn} \mathrm{15,} \mathrm{Cu} \mathrm{0.9,} \mathrm{pH} \mathrm{5.5,} \mathrm{EC} 2.25 \mathrm{mS} \times \mathrm{cm}^{-1}$; NS II: (in mmol $\left.\times \mathrm{dm}^{-3}\right) \mathrm{N}^{-\mathrm{NH}_{4}}>0.7, \mathrm{~N}^{-\mathrm{NO}_{3}}$ 12.2, P 5.5, K 10.5, Ca 3.2, Mg 1.3, $\mathrm{S}_{-} \mathrm{SO}_{4} 2.1,\left(\mu \mathrm{mol} \times \mathrm{dm}^{-3}\right)$ : Fe 30, Mn 30, Zn 15, Cu 0.9, pH 5.5, EC $2.70 \mathrm{mS} \times \mathrm{cm}^{-1}$.

\section{Seed inoculation and plant cultivation}

Non-inoculated seeds (control treatment) were sown into rockwool cubes which were saturated with the respective nutrients (NS I and NS II) 48 hours before sowing. One part of seeds was inoculated with a $10 \%$ water-based solution of Effective Microorganisms (EM-A), soaking lettuce seeds in it for 30 minutes before sowing; then, seeds were sown into rockwool cubes as in the case of the control treatment. After 22 days (3-4 leaf stage), seedlings were transplanted into rockwool blocks $(10 \times 10 \times 10 \mathrm{~cm})$. Plants were placed in PE $3.45 \mathrm{dm}^{3}$ containers, wrapped with black and white plastic film, forming hydroponic stagnation. Plants were watered according to the needs with the nutrient solution at a rate about $0.05-0.15 \mathrm{dm}^{3} \times$ plant $^{-1}$. During the whole experimental period, both with assimilation illumination and without assimilation illumination of plants, a constant temperature of $18-19^{\circ} \mathrm{C}$ was maintained.

\section{Assimilation illumination of plants}

An independent experiment was carried out: in a room without assimilation illumination $(\mathrm{C} 1)$ and in a room equipped in an assimilation illumination system (C2) with high pressure sodium lamps $(400 \mathrm{~W})$. This illumination was used throughout the growing period of plants, 9 hours per day (from 8 am till $5 \mathrm{pm}$ ). 


\section{Chemical analysis}

For the chemical analysis of the nutritional status, the aboveground parts of plants (after forty days of cultivation) were taken; they were dried in a temperature range of $45-50^{\circ} \mathrm{C}$ and then homogenized. For the determination of the total content of $\mathrm{N}, \mathrm{P}, \mathrm{K}, \mathrm{Ca}$, $\mathrm{Mg}$, and $\mathrm{Na}$, the plant material was mineralized in concentrated sulfuric acid $\left(90 \% \mathrm{H}_{2} \mathrm{SO}_{4}\right)(\mathrm{K}$ le i b e r and K o m o s a , 2010). After mineralization, the following were determined: $\mathrm{N}$-total - by the Kjeldahl distillation method; P - colourimetrically with ammonium molybdate (by Schillak); K, Ca, Mg, Na - by AAS method (in Carl-Zeiss Jena apparatus).

\section{Microbiological analysis}

Samples intended for microbiological analysis were collected twice. On the day of transplanting lettuce plants, the microbiological nutrients were applied, the mineral wool, dried up with nutrients NS I and NS II and also a solution of EM that was made for dressing lettuce seed. On the day the experiment was finished, an analysis of the microbiological medium of NS I and NS II was taken from the root part of the plants that were dressed, and also from the undressed EM-A from the quarters of both the assimilating illuminated and non-illuminated plants. Samples were collected by cutting down some parts of the dried medium from the root area from 15 places, for each combination, forming a sample mixture. The growth in the total number of bacteria, actinobacteria, fungi, copiotrophic microorganisms and oligotrophic microorganisms was determined in relation to the sample combination. The number of microorganism groups was determined by culturing microorganisms on Petri dishes on appropriate growth media - standard count agar by MERCK for bacteria, medium according to Martin for fungi (M a r t i n, 1950), medium according to Pochon for actinobacteria (Grabińska-Leniowska, 1999), NB (nutrient broth) for the cultivation of copiotrophs, and diluted nutrient broth (DNB) for the cultivation of oligotrophs (O ht a and Hattori, 1980).

After completing consecutive diluted samples of medium for the cultivation of fungi, the $10^{4}$ dilution was used, while for the rest of the microorganism groups the $10^{5}$ dilution was used. Microorganisms were incubated at a temperature of $28^{\circ} \mathrm{C}$, with the exception of fungi which cultured at $24^{\circ} \mathrm{C}$. The reading of the results consisted in counting the number of microorganisms that grew on Petri dishes for all the microorganism groups after a period of 7 days, with the exception of oligotrophs which were counted after 21 days.

\section{Measurement and statistical analysis}

Biometrical measurements took into account the following: seed germination, quantity of leaves per plant (LQ), surface area of the biggest leaves of plants (SBL), leaf greenness index (measured with a Konica-
-Minolta camera SPAD-502), total fresh weight (TFW), total dry weight (TDW), percentage of dry matter (\% $\mathrm{DM}$ ), nutrient (N, P, K, Ca, Mg, Na) uptake by the above-ground parts of the plant. The obtained results of the statistical analysis were evaluated by Duncan's test $(\mathrm{p}=$ $0.05)$. The results of the microbiological analysis were evaluated by Tukey's test $(\mathrm{p}=0.05)$.

\section{RESULTS}

\section{Biometric parameters}

The rate of seed germination on the days after sowing is shown in Figure 1, whereas the rate of leaf production is shown in Figure 2. The study found a significant difference between treatments. The fastest seed germination was observed in the treatment with seeds inoculated with the EM-A solution, using NS II $\left(3^{\text {rd }}-5^{\text {th }}\right.$ day). In effect, the lowest germination rate characterized seeds inoculated with the EM-A solution, using NS I $\left(3^{\text {rd }}-5^{\text {th }}\right.$ day $)$. On the last day $\left(9^{\text {th }}\right)$, the percentage of germination was significantly highest in case of NS I, but the lowest in case of the same nutrient solution with EM-A application. One can assume that an increase in the level of particular nutrients in NS II positively influenced the biological activity of microorganisms; in that, NS had a positive effect on their stimulating influence on germinating plants during the first 5 days - but later (from the $5^{\text {th }}$ to $9^{\text {th }}$ day), a positive influence of NS I was found. EM-A application generally decreased the percentage of seed germination.

The highest quantity of leaves was found both in the case of assimilation illumination and without such assimilation illumination in plants watered with NS II, with seed inoculation with EM-A at the same time. The chemical composition of the nutrient solution was shown to have a significant influence on the biometrical parameters of plants (Tables 1, 4). NS II had a positive effect on LQ, SBL, TFW and TDW, at the same time reducing the value of dry matter in the above-ground parts of the plant (a reduction by about $21.8 \%$ ). However, its influence on the leaf greenness index (SPAD units) was not demonstrated.

Similar to the case of the nutrient solution, supplemental lighting of plants was shown to have a significant effect on LQ, SBL, TFW and TDW. It did not, however, have any significant influence on the percentage of DM and leaf greenness index (SPAD units).

\section{The nutritional status of plants}

The chemical composition of the nutrient solution was found to have a significant influence on the nitrogen and phosphorus status (Table 2). In the case of the other nutrients $(\mathrm{K}, \mathrm{Ca}, \mathrm{Mg}, \mathrm{Na})$, the nutrient status of plants under NS I and NS II did not differ significantly. However, there was an unproven statistical trend that the nutritional status of plants improved in the case 
of plants that were inoculated with EM-A, in comparison to the control treatment. In the present study, plant illumination was not shown to affect plant nutrient status, with the exception of phosphorus whose content decreased significantly.

\section{Nutrient uptake}

The study found a significant effect of NS (NS II in relation to NS I) and assimilation illumination of plants on the increase of all absorbed nutrients (Table $3)$. In the case of application of EM inoculation, the differences were not proven.

\section{Number of selected microorganisms}

The first microbiological analysis determined the number of microorganisms in the EM-A solution (Fig. 4).

Among many anthropogenic factors that have a significant influence on microorganisms, fertilization is the biggest one (B a r a b a s z and V oř iš e k, 2002). The microbiological analysis of nutrients NS I and NS II and the mineral wools in which they were dried showed significant differences in the number of microorganism groups that were tested, with the exception of fungi; their presence was not noted based on already analysis ones. The remaining groups of microorganisms showed a significant growth in numbers during the first analysis in the NS II nutrients and mineral wools, with which it was dried (Fig. 3).

A similar growth trend in the number of microorganisms in the case of NS II was also noted during the second analysis (Fig. 5). The NS II nutrient solution, which is characterized by higher contents of particular chemical components, turned out to be the best place for intensive growth in the total number of bacteria, actinobacteria and copiotrophs. Typical is the confirmation of similar tendency changes in the number of oligotrophs. The term oligotroph is related to bacteria that grow on lower concentrations of nutrient components, however, only during the first phase of cultivation. Nevertheless, during successive inoculations (sowings) these bacteria increased in numbers also in nutrient rich substrates (Paul and $\mathrm{Clark}$, 2000). These are bacteria that show little changes as regards to their quantity and activity. In the analyzed experiment, however, their growth in number in richer medium (in case of NS II) became very significant in comparison to the NS I medium.

The analysis of the composition of microbiological medium in which seeds that were inoculated with the EM-A solution were controlled did not show any significant influence of inoculated seeds on the changes in the number of analyzed groups of microorganisms within the medium. It only showed a tendency towards less significant growth in the colony numbers of already tested microorganisms in the treatments with dressed lettuce seeds, but no statistical significance was found. This observation could be a result of the stimulating activity of microorganisms contained in the biological preparation on the observed plant growth and development, in that way, production by them more of root secretion.

Comparing the changes in the numbers of microorganism groups analyzed, significant changes in the results were observed in the case of both plants under assimilation illumination and those that were not under such conditions. In the case of assimilation illumination of plants, there was observed only a small increase in the number of bacteria, actinobacteria, copiotrophs and oligotrophs.

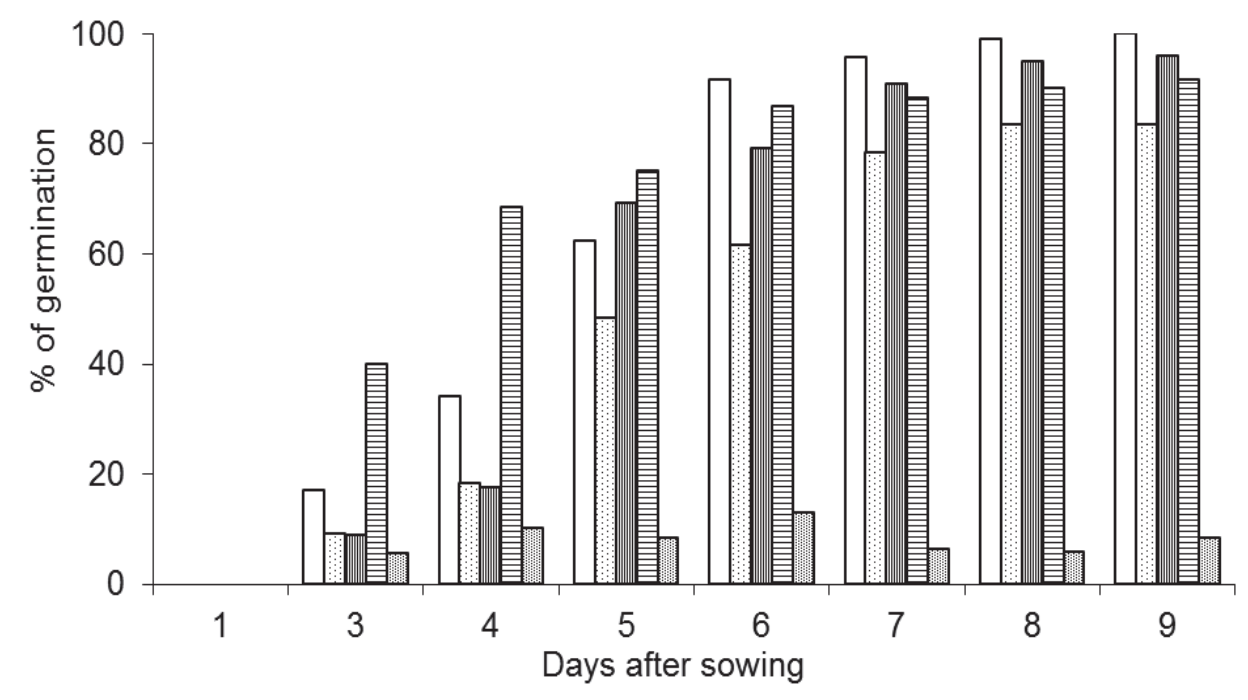

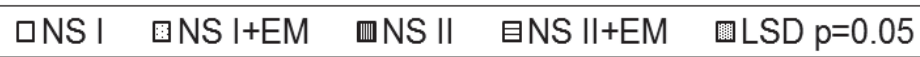

Fig. 1 Seed germination rate ( $\%$ of germination). 


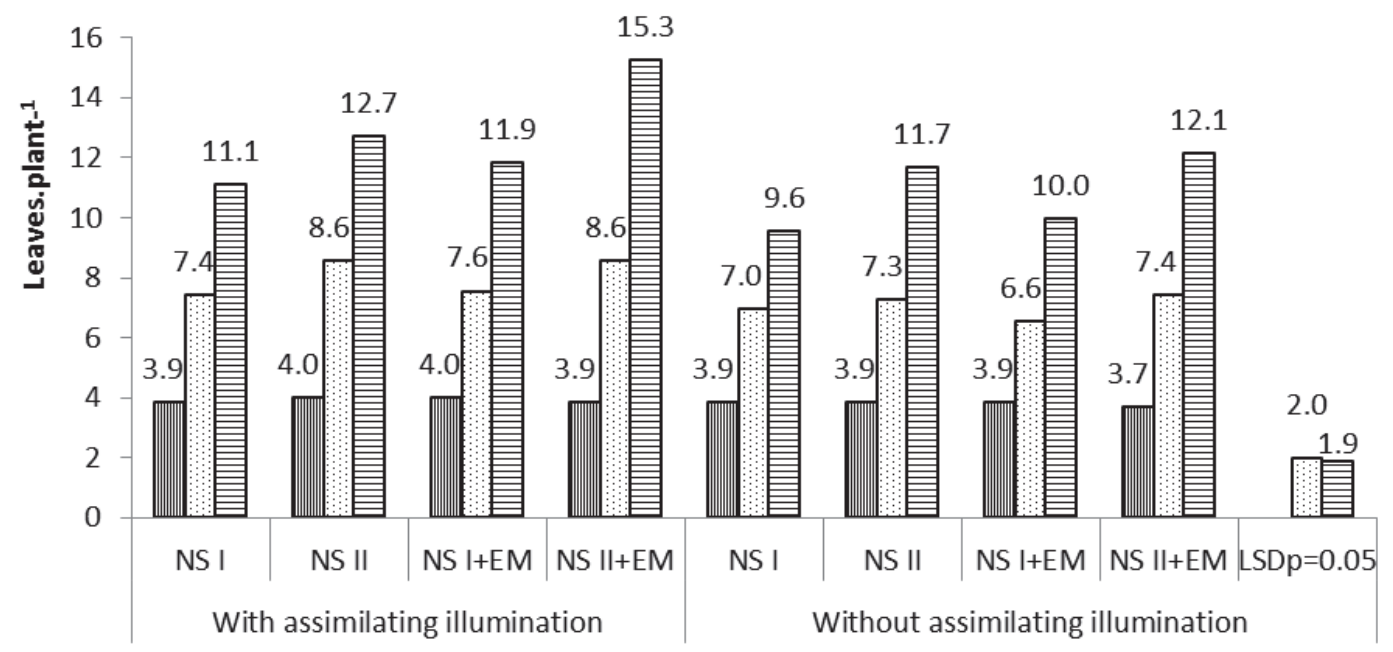

Fig. 2 Leaf production rate (number of leaves $\times$ plant $^{-1}$ ).

四17th day 924 th day 目40th day

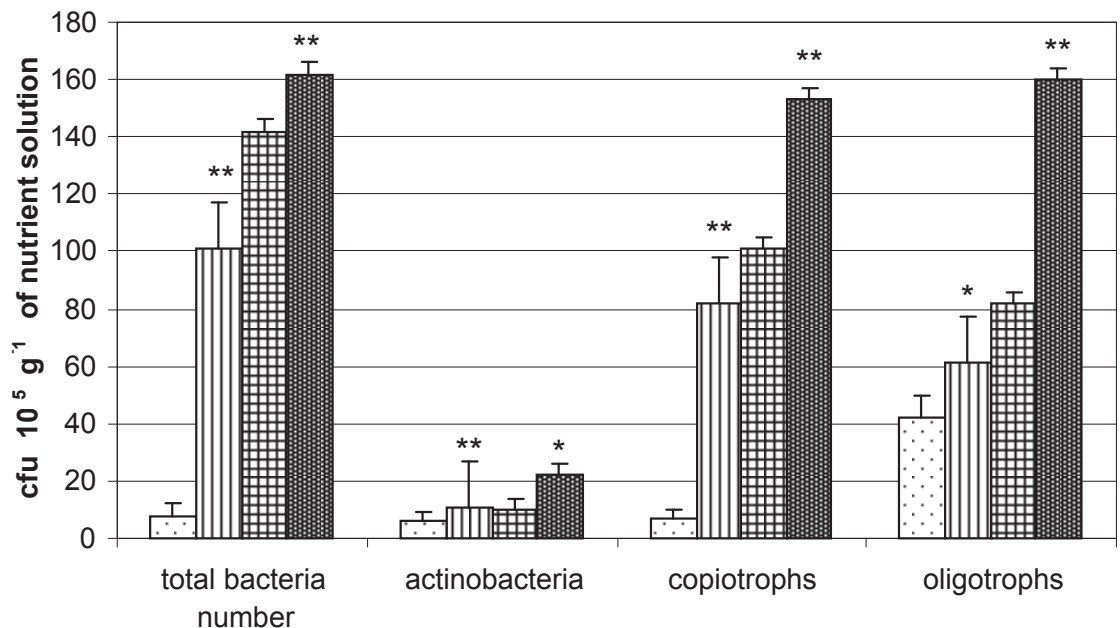

$\square \mathrm{NS}$ I

๓NS II

田 rockwool + NS I

图 rockwool + NS II

${ }^{*} p<0,05$ Significant difference

${ }^{* *} p<0.01$ highly significant difference number

Fig. 3 Number of microorganisms in relation to the chemical composition of nutrient solutions on the day of sowing (cfu $10^{5} \mathrm{~g}^{-1}$ of nutrient solution).

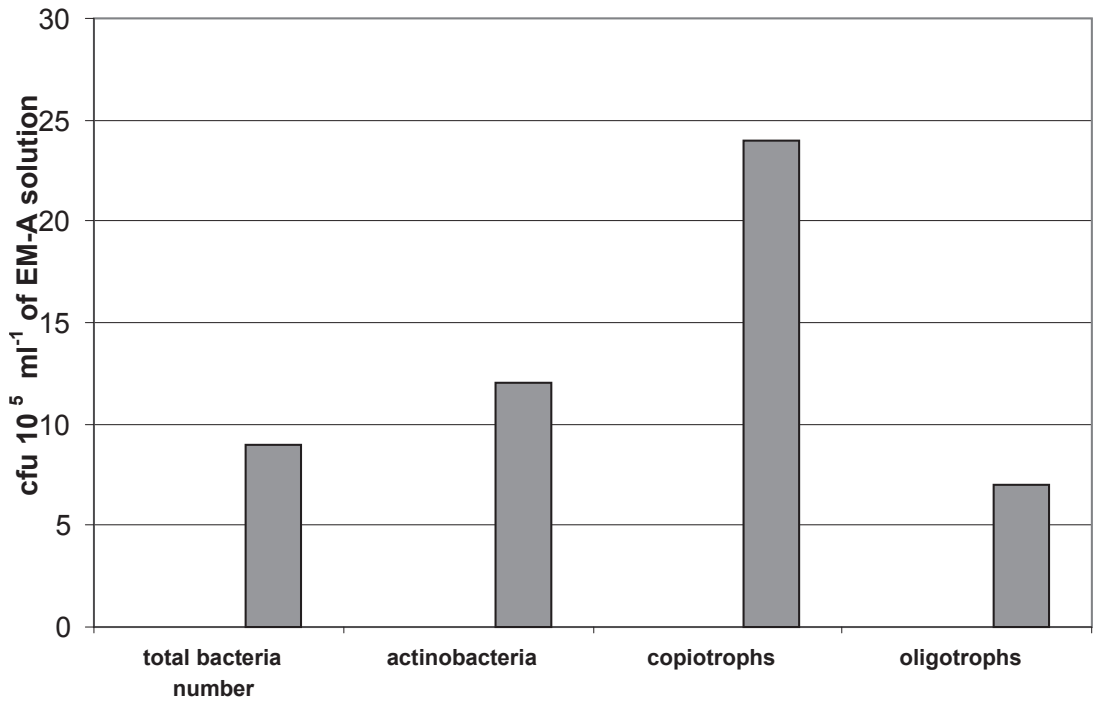

Fig. 4 Number of microorganisms in EM-A solution (cfu $10^{5} \mathrm{ml}^{-1}$ of EM-A solution). 


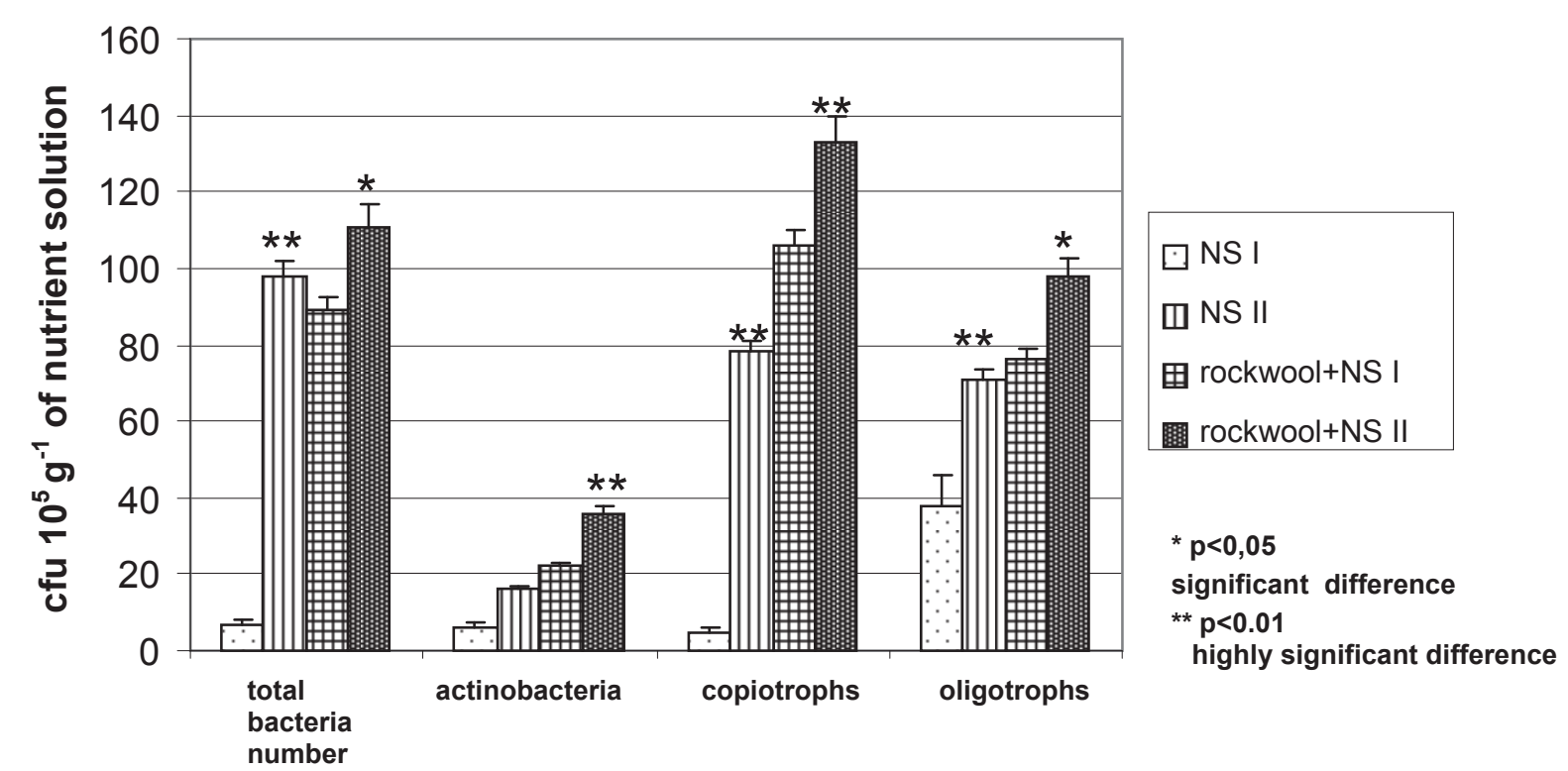

Fig. 5 Number of microorganisms in relation to the chemical composition of nutrient solutions on the last day of the experiment (cfu $10^{5} \mathrm{~g}^{-1}$ of nutrient solution).

Table 1

Mean values of growth characters

\begin{tabular}{|c|c|c|c|c|c|c|c|}
\hline \multirow{2}{*}{$\begin{array}{l}\text { Nutrient solution } \\
\text { (A) }\end{array}$} & \multirow{2}{*}{$\begin{array}{l}\text { EM-A inoculation } \\
\text { (B) }\end{array}$} & \multirow{2}{*}{ LQ } & SBL & TFW * & TDW $*$ & DM & \multirow{2}{*}{ SPAD units } \\
\hline & & & $\left(\mathrm{cm}^{2}\right)$ & (g) & (g) & $(\%)$ & \\
\hline \multicolumn{8}{|c|}{ Without assimilation illumination (C1) } \\
\hline NS I & Control & $9.57 \mathrm{a}$ & $15.0 \mathrm{a}$ & $250.0 \mathrm{a}$ & $15.0 \mathrm{a}$ & $6.00 \mathrm{ab}$ & $31.1 \mathrm{a}$ \\
\hline NS II & Control & $11.71 \mathrm{~b}$ & $36.0 \mathrm{~b}$ & $507.0 \mathrm{~b}$ & $26.0 \mathrm{~b}$ & $5.13 \mathrm{a}$ & $29.3 \mathrm{a}$ \\
\hline NS I & EM-A & $10.02 \mathrm{a}$ & $11.0 \mathrm{a}$ & $191.0 \mathrm{a}$ & $13.0 \mathrm{a}$ & $6.81 \mathrm{~b}$ & $30.1 \mathrm{a}$ \\
\hline NS II & EM-A & $12.14 \mathrm{~b}$ & $35.0 \mathrm{~b}$ & $588.0 \mathrm{~b}$ & $30.0 \mathrm{~b}$ & $5.10 \mathrm{a}$ & $29.7 \mathrm{a}$ \\
\hline \multicolumn{8}{|c|}{ With assimilation illumination $(\mathrm{C} 2)$} \\
\hline NS I & Control & $11.14 \mathrm{ab}$ & $24.0 \mathrm{a}$ & $301.0 \mathrm{a}$ & $22.0 \mathrm{ab}$ & $7.31 \mathrm{~b}$ & $33.8 \mathrm{a}$ \\
\hline NS II & Control & $12.71 \mathrm{~b}$ & $56.0 \mathrm{~b}$ & $1015.0 \mathrm{c}$ & $54.0 \mathrm{c}$ & $5.32 \mathrm{a}$ & $34.4 \mathrm{a}$ \\
\hline NS I & EM-A & $11.86 \mathrm{~b}$ & $18.0 \mathrm{a}$ & $280.0 \mathrm{a}$ & $20.0 \mathrm{ab}$ & $7.14 b$ & $33.4 \mathrm{a}$ \\
\hline NS II & EM-A & $15.28 \mathrm{c}$ & $50.0 \mathrm{~b}$ & $1006.0 \mathrm{c}$ & $58.0 \mathrm{c}$ & $5.77 \mathrm{a}$ & $33.7 \mathrm{a}$ \\
\hline \multirow{2}{*}{ Mean for A } & NS I & $10.65 \mathrm{a}$ & $17.0 \mathrm{a}$ & $255.5 \mathrm{a}$ & $17.5 \mathrm{a}$ & $6.82 \mathrm{~b}$ & $32.1 \mathrm{a}$ \\
\hline & NS II & $12.96 \mathrm{~b}$ & $44.3 \mathrm{~b}$ & $779.0 \mathrm{~b}$ & $42.0 \mathrm{~b}$ & $5.33 \mathrm{a}$ & $31.8 \mathrm{a}$ \\
\hline \multirow{2}{*}{ Mean for B } & Control & $11.28 \mathrm{a}$ & $32.8 \mathrm{a}$ & $518.3 \mathrm{a}$ & $29.3 \mathrm{a}$ & $5.94 \mathrm{a}$ & $32.2 \mathrm{a}$ \\
\hline & EM-A & $12.33 \mathrm{a}$ & $28.5 \mathrm{a}$ & 516.3 a & $30.3 \mathrm{a}$ & $6.21 \mathrm{a}$ & $31.7 \mathrm{a}$ \\
\hline \multirow{2}{*}{ Mean for $\mathrm{C}$} & Without AI & $10.87 \mathrm{a}$ & $24.3 \mathrm{a}$ & $384.0 \mathrm{a}$ & $21.0 \mathrm{a}$ & $5.47 \mathrm{a}$ & $30.1 \mathrm{a}$ \\
\hline & With AI & $12.75 \mathrm{~b}$ & $37.0 \mathrm{~b}$ & $650.5 \mathrm{~b}$ & $38.5 \mathrm{~b}$ & $5.92 \mathrm{a}$ & $33.8 \mathrm{a}$ \\
\hline
\end{tabular}

* TFW and TDW - weight of 100 plants; descriptions for all the tables and figures: NS I - nutrient solution I; NS II - nutrient solution II; AI - assimilation illumination; the quantity of leaves per plant (LQ), area surface of the biggest leaves of plants (SBL), relative chlorophyll content (SPAD units), total fresh weight (TFW), total dry weight (TDW), percentage (\%) of dry matter $(\% \mathrm{DM})$ 
Table 2

Nutrient content in lettuce leaves (\% DM in the aboveground parts)

\begin{tabular}{|c|c|c|c|c|c|c|c|}
\hline $\begin{array}{l}\text { Nutrient solution } \\
\text { (A) }\end{array}$ & $\begin{array}{c}\text { EM-A } \\
\text { inoculation (B) }\end{array}$ & $\mathrm{N}$ & $\mathrm{P}$ & $\mathrm{K}$ & $\mathrm{Ca}$ & $\mathrm{Mg}$ & $\mathrm{Na}$ \\
\hline \multicolumn{8}{|c|}{ Without assimilation illumination $(\mathrm{C} 1)$} \\
\hline NS I & Control & $4.13 \mathrm{~b}$ & $0.57 \mathrm{a}$ & $8.34 \mathrm{abc}$ & $1.29 \mathrm{a}$ & $0.72 \mathrm{a}$ & $0.14 \mathrm{c}$ \\
\hline NS II & Control & $4.90 \mathrm{c}$ & $1.31 \mathrm{f}$ & $9.11 \mathrm{bc}$ & $1.35 \mathrm{a}$ & $0.72 \mathrm{a}$ & $0.14 \mathrm{c}$ \\
\hline NS I & EM-A & $4.11 \mathrm{~b}$ & $0.92 \mathrm{~d}$ & $7.64 \mathrm{a}$ & $1.46 \mathrm{a}$ & $0.76 \mathrm{a}$ & $0.13 \mathrm{a}$ \\
\hline NS II & EM-A & $5.48 \mathrm{~d}$ & $1.13 \mathrm{e}$ & $9.20 \mathrm{bc}$ & $1.37 \mathrm{a}$ & $0.74 \mathrm{a}$ & $0.13 \mathrm{ab}$ \\
\hline \multicolumn{8}{|c|}{ With assimilation illumination (C2) } \\
\hline NS I & Control & $3.64 \mathrm{bc}$ & $0.71 \mathrm{~b}$ & $8.13 \mathrm{ab}$ & $1.46 \mathrm{a}$ & $0.72 \mathrm{a}$ & $0.13 \mathrm{abc}$ \\
\hline NS II & Control & $5.15 \mathrm{~d}$ & $0.92 \mathrm{~d}$ & $8.85 \mathrm{abc}$ & $1.29 \mathrm{a}$ & $0.75 \mathrm{a}$ & $0.13 \mathrm{abc}$ \\
\hline NS I & EM-A & $4.26 \mathrm{~b}$ & $0.76 \mathrm{c}$ & $8.50 \mathrm{abc}$ & $1.34 \mathrm{a}$ & $0.81 \mathrm{~b}$ & $0.13 \mathrm{abc}$ \\
\hline NS II & EM-A & $5.33 \mathrm{~d}$ & $0.91 \mathrm{~d}$ & $9.46 \mathrm{c}$ & $1.47 \mathrm{a}$ & $0.79 a b$ & $0.14 \mathrm{bc}$ \\
\hline \multirow{2}{*}{ Mean for A } & NS I & $4.04 \mathrm{a}$ & $0.74 \mathrm{a}$ & $8.15 \mathrm{a}$ & $1.39 \mathrm{a}$ & $0.75 \mathrm{a}$ & $0.13 \mathrm{a}$ \\
\hline & NS II & $5.21 \mathrm{~b}$ & $1.07 \mathrm{~b}$ & $9.16 \mathrm{a}$ & $1.37 \mathrm{a}$ & $0.75 \mathrm{a}$ & $0.14 \mathrm{a}$ \\
\hline \multirow{2}{*}{ Mean for B } & Control & $4.46 \mathrm{a}$ & $0.88 \mathrm{a}$ & $8.61 \mathrm{a}$ & $1.35 \mathrm{a}$ & $0.73 \mathrm{a}$ & $0.14 \mathrm{a}$ \\
\hline & EM-A & $4.79 \mathrm{a}$ & $0.93 \mathrm{a}$ & $8.70 \mathrm{a}$ & $1.41 \mathrm{a}$ & $0.77 \mathrm{a}$ & $0.13 \mathrm{a}$ \\
\hline \multirow{2}{*}{ Mean for $\mathrm{C}$} & Without AI & $4.66 \mathrm{a}$ & $0.98 \mathrm{~b}$ & $8.57 \mathrm{a}$ & $1.37 \mathrm{a}$ & $0.74 \mathrm{a}$ & $0.14 \mathrm{a}$ \\
\hline & With AI & $4.59 \mathrm{a}$ & $0.82 \mathrm{a}$ & $8.74 \mathrm{a}$ & $1.39 \mathrm{a}$ & $0.77 \mathrm{a}$ & $0.13 \mathrm{a}$ \\
\hline
\end{tabular}

Table 3

Nutrient uptake by the aboveground parts of the plant $\left(\mathrm{mg} \times\right.$ plant $\left.^{-1}\right)$

\begin{tabular}{|c|c|c|c|c|c|c|c|}
\hline $\begin{array}{l}\text { Nutrient solution } \\
\text { (A) }\end{array}$ & $\begin{array}{l}\text { EM-A inoculation } \\
\text { (B) }\end{array}$ & $\mathrm{N}$ & $\mathrm{P}$ & K & $\mathrm{Ca}$ & $\mathrm{Mg}$ & $\mathrm{Na}$ \\
\hline \multicolumn{8}{|c|}{ Without assimilation illumination (C1) } \\
\hline NS I & Control & $6.20 \mathrm{a}$ & $0.86 \mathrm{a}$ & $12.51 \mathrm{a}$ & $1.94 \mathrm{a}$ & $1.08 \mathrm{a}$ & $0.21 \mathrm{a}$ \\
\hline NS II & Control & $12.74 \mathrm{~b}$ & $3.41 \mathrm{~b}$ & $23.69 \mathrm{~b}$ & $3.51 \mathrm{~b}$ & $1.87 \mathrm{~b}$ & $0.36 \mathrm{~b}$ \\
\hline NS I & EM-A & $5.34 \mathrm{a}$ & $1.20 \mathrm{a}$ & $9.93 \mathrm{a}$ & $1.90 \mathrm{a}$ & $0.99 \mathrm{a}$ & $0.17 \mathrm{a}$ \\
\hline NS II & EM-A & $16.44 b$ & $3.39 \mathrm{~b}$ & $27.60 \mathrm{~b}$ & $4.11 \mathrm{bc}$ & $2.22 \mathrm{~b}$ & $0.39 \mathrm{~b}$ \\
\hline \multicolumn{8}{|c|}{ With assimilation illumination (C2) } \\
\hline NS I & Control & $8.01 \mathrm{a}$ & $1.56 \mathrm{ab}$ & $17.89 \mathrm{ab}$ & $3.21 \mathrm{~b}$ & $1.58 \mathrm{ab}$ & $0.29 \mathrm{a}$ \\
\hline NS II & Control & $27.81 \mathrm{c}$ & $4.97 \mathrm{c}$ & $47.79 \mathrm{~b}$ & $6.97 \mathrm{c}$ & $4.05 \mathrm{c}$ & $0.70 \mathrm{c}$ \\
\hline NS I & EM-A & $8.52 \mathrm{a}$ & $1.52 \mathrm{ab}$ & $17.00 \mathrm{ab}$ & $2.68 \mathrm{~b}$ & $1.62 \mathrm{ab}$ & $0.26 \mathrm{a}$ \\
\hline NS II & EM-A & $30.91 \mathrm{c}$ & $5.28 \mathrm{c}$ & $54.87 \mathrm{~b}$ & $8.53 \mathrm{c}$ & $4.58 \mathrm{c}$ & $0.81 \mathrm{c}$ \\
\hline \multirow{2}{*}{ Mean for A } & NS I & $7.02 \mathrm{a}$ & $1.28 \mathrm{a}$ & $14.33 \mathrm{a}$ & $2.43 \mathrm{a}$ & $1.32 \mathrm{a}$ & $0.23 \mathrm{a}$ \\
\hline & NS II & $21.98 \mathrm{~b}$ & $4.26 \mathrm{~b}$ & $38.49 \mathrm{~b}$ & $5.78 \mathrm{~b}$ & $3.18 \mathrm{~b}$ & $0.57 \mathrm{~b}$ \\
\hline \multirow{2}{*}{ Mean for B } & Control & $13.69 \mathrm{a}$ & $2.70 \mathrm{a}$ & $25.47 \mathrm{a}$ & $3.91 \mathrm{a}$ & $2.15 \mathrm{a}$ & $0.39 \mathrm{a}$ \\
\hline & EM-A & $15.30 \mathrm{a}$ & $2.85 \mathrm{a}$ & $27.35 \mathrm{a}$ & $4.30 \mathrm{a}$ & $2.35 \mathrm{a}$ & $0.41 \mathrm{a}$ \\
\hline \multirow{2}{*}{ Mean for $\mathrm{C}$} & Without AI & $10.18 \mathrm{a}$ & $2.21 \mathrm{a}$ & $18.43 \mathrm{a}$ & $2.86 \mathrm{a}$ & $1.54 \mathrm{a}$ & $0.28 \mathrm{a}$ \\
\hline & With AI & $18.81 \mathrm{~b}$ & $3.33 \mathrm{~b}$ & $34.39 \mathrm{~b}$ & $5.35 \mathrm{~b}$ & $2.96 \mathrm{~b}$ & $0.52 \mathrm{~b}$ \\
\hline
\end{tabular}


Table 4

Relative influence of experimental factors on the characteristics of plant biometrics (combination of NS I, EM-A control and non-plant assimilation illumination accepted as 100\%)

\begin{tabular}{ccccccc}
\hline Factor & LQ & SBL & TFW & TDW & \% DM & SPAD units \\
\hline NS I & 100.0 & 100.0 & 100.0 & 100.0 & 100.0 & 100.0 \\
NS II & 121.7 & 261.8 & 304.9 & 240.0 & 78.2 & 99.1 \\
EM-Control & 100.0 & 100.0 & 100.0 & 100.0 & 100.0 & 100.0 \\
EM-A & 109.3 & 86.9 & 99.6 & 103.4 & 104.5 & 98.4 \\
Without AI (C1) & 100.0 & 100.0 & 100.0 & 100.0 & 100.0 & 100.0 \\
With AI (C2) & 117.3 & 152.3 & 169.4 & 183.3 & 108.2 & 112.7 \\
\hline
\end{tabular}

\section{DISCUSSION}

It has been found that light modifies TFW, TDW, and also the plant height and surface area of leaves (V alverde et al. 2009). It is not only the quantity of light, but also the quality of light that influences significantly both the number of leaves per plant and the content of dry matter (A u t i o and Vo i p i o, 1997). It has been confirmed that light (an experiment conducted during the spring and summer periods) has an effect on plant biometrical parameters (M a r š i c and $\mathrm{Os} \mathrm{v}$ ald, 2002).

Among the factors that influence plant nutrient status, there is the nitrate content in the nutrient solution used for plant fertigation (M arš ic and $\mathrm{Osvald}$, 2002). Earlier studies show in addition had it that a higher quantity of fertilizer applied significantly influences the nitrate status of lettuce leaves cultivated in NFT, compared to illumination and regulatory growth (M y c z k ow s ki et al. 1990). It has been confirmed that in hydroponic lettuce cultivation systems harvested plants are characterized by good quality shown, amongst others, by lower nitrate content ( $\mathrm{V}$ a l v e r d e et al. 2009).

Some previous studies found a positive effect of nitrogen fertilization rates on the content of nitrogen, potassium, calcium and magnesium in plant tissues (J arosz and D zida, 2006; K le iber et al. 2009). J a r o s z and D zida (2006) showed smaller contents of phosphorus, potassium and calcium and, at the same time, higher nitrogen and magnesium contents. In all experimental combinations, more than $1 \%$ $\mathrm{Ca} \mathrm{FW}$ was found. A reduction in the content of this nutrient below the above optimal value may have an influence on the appearance of physiological perturbation on plants (Kirkby and Pilbe a m, 1984).

It has been reported that a close linear relationship exists between the contents of fresh matter in lettuce and daily radiation during the autumn - winter period, which enables one to determine the cultivation time frame under such conditions (K o b r y ń, 1989).
Some scientists have claimed that the interaction between illumination conditions and growth regulators (GA3, Kinetin, and GA3/Kinetin mixture) has a positive influence on the growth of fresh matter and also the contents of dissolved sugar in leaves (R o ż e k et al. 1989).

The present study did not show any significant influence of seed inoculation with EM on the observed plant biometrical parameters. Also earlier studies did not show unequivocally and directly the influence of the application of useful microorganisms on the number of leaves and the total surface area of leaves - the reaction of cucumber plants depended on the types of microorganisms used (A b d e la zi z and P o k l u d a, 2009). EM was found to have a positive effect in protection of winter wheat against fungal diseases (B o lig łow a and Gle ń, 2008). A mixture of Effective Microorganisms with molasses increased the yielding of some vegetable species (Daly and Stewart, 1999) and ornamental plant species (Górski and Kleiber, 2010).

Similar positive effects of EM application on plant development were observed in rice cultivation, in which a significant plant growth and the quality of harvested crops (I w a i s h i, 2000) as well as in case of rose and gerbera where EM influenced significantly on growth and yielding mentioned flowers. A different observation was earlier made as regards the negative influence of EM-A on growth and yield of lettuce cultivated in pots in brown soil ( $\mathrm{Ku} \mathrm{charski}$ and $\mathrm{J} \mathrm{a-}$ strzębska, 2005).

A positive effect of nitrogen and potassium fertilization on lettuce yield was shown by previous researches (Kozik and Ruprik, 2000; Jarosz and Dzida, 2006; Kowalska et al. 2006). There is a significant influence of EC nutrient growth (in the range from 0.83 to $\left.2.81 \mathrm{mS} \times \mathrm{cm}^{-1}\right)$ on the increase in the quantity of dry matter in lettuce leaves (A n d ri o 10 et al. 2005).

The large abundance of components, that were contained in NS II nutrient solution were probably eliminated by the occurrence of competition between 
microorganisms, on the availability of nutrients, allowing at the same time, free, unlimited supply of nutrients, and development of microorganisms. A significant increase of total number of bacteria was noted, actinobacteria and copiotrophs, developing particularly intensively in the case of inflow of nutrients to the medium, is a reflection to the number of those groups in the chemical nutrient medium of NS II. This type of tendency was also noted in the case of soil analysis with different available sources of nutrients for microorganisms (Martens et al. 1992; Paul and Clark, 2000).

Many researches, on the other hand, confirm the positive influence of plant secretion on the stimulation that accompanies their microfloras (W i e l g o s z, 1999; Pięt a and Patkowska, 2001). Moreover, a non-significant increase in the number of microorganisms could as well be as a consequence of an additional number of Effective Microorganisms that were introduced to the medium of inoculated seeds.

\section{CONCLUSIONS}

The present study concentrated on the influence of the chemical composition of the nutrient solution (NS I, NS II), seed inoculation with Effective Microorganisms (EM-A), and assimilation illumination (IA) on the growth, development and nutritional status of lettuce (Lactuca sativa L.) in hydroponic cultivation and microbiological changes in the rhizosphere. The study found a positive effect of EM and, at the same time, the application of NS II on the production of the highest quantity of leaves per plant. Also, the significant influence of nutrient solution composition on plant biological parameters was confirmed. An increase nutrient concentration positively influenced the total number of leaves, surface area of the biggest leaf, total fresh weight, total dry weight and at the same time reduced the content of dry matter in the aboveground parts of the plant. The use of plant assimilation illumination during light deficiency had a positively effect on plant growth: it increased the total number of leaves per plant, surface area of the biggest leaves, total fresh weight, and total dry weight. The nutrient solution composition was found to have a significant influence on the nitrogen and phosphorus status of plants. Nonetheless, the influence of plant illumination on their nutrient status was shown, with the exception of phosphorus whose content decreased significantly. However, there was an unproven statistical trend that the nutritional status of plants improved in the case of plants that were inoculated with EM-A, in comparison to the control treatment. A significant influence of EC level and assimilation illumination on the growth of all absorbed macronutrients was confirmed. However, in the case of the application of EM inoculation, there was an unproven statistical trend towards an increase in nutrients taken up by the aboveground parts of the plant. In a light-deficit situation, it is possible to produce good quality plants and fresh vegetables using a balanced nutrient solution, microorganisms, and assimilation illumination. In the present study, chemical nutrients had a significant influence on the change in the quantity of analyzed microorganism groups. No significant differences were found in the changes in microbiological status of media in the case of assimilation illumination and in the case of seeds inoculated with EM solutions. The research on the use of Effective Microorganisms in vegetable cultivation in rockwool should be continued.

\section{Acknowledgements}

Research supported by the Ministry of Science and Higher Education of Poland as part of the statutory activities of the Department of Plant Nutrition and Department of General and Environmental Microbiology, University of Life Sciences in Poznań.

\section{REFERENCES}

Abdelaziz M.E, Pokluda R. 2009. Response of cucumbers grown on two substrates in an open soilless system to inoculation with microorganisms. Acta Hort. 819: $157-164$.

Adamicki F., Nawrocka B., Badelek E., Robak J., Rogowska M., Stępowska A. 2005. Methods of Integral Lettuce Production Under Cover. Main Inspectorate of Plant Health and Seed Inspection, Warsaw.

A mjadi K., Hussain K. 2005. Integrating food hygiene into quantity food production systems. Nutrition \& Food Science, 35 (3): 169-183. http://dx.doi.org/ $10.1108 / 00346650510594921$

Andriolo J. L., Luz G.L., Witter M.H., Godoi R.S., Barros G.T., Bortolotto O.C. 2005. Growth and yield of lettuce plants under salinity. Hort. Brasileira, Brasília, 23 (4): 931-934. http://dx.doi. org/10.1590/S0102-05362005000400014

Autio J., Voipio I. 1997. Growth of leaf lettuce under fluctuating light conditions. Acta Hort. 435: 193-200.

B a 11 N. J . 1998. Plant protection and eco-labelling of primary products. New Zealand Plant Protection, Soc. Inc., Lincoln University, Canterbury, New Zealand.

B a rabasz W., Vořišek K. 2002. Biodiversity of microorganisms in soil environment. Activity of microorganisms in different environments, Proceed. of all-Poland Microbiol. Symp., Agricult. University, Krakow: 26-27.

Bol R., Kandeler E., Amelung A., Glaser B., Marx M.C., Preedy N., Lorenz K. 2003. Short-term effects of dairy slurry amendment on carbon 
sequestration and enzyme activities in a temperature grassland. Soil Biol. Biochem. 35: 1411-1421.

Boligłowa E., Gleń K. 2008. Assessment of effective microorganisms activity (EM) in winter wheat protection against fungal diseases. Ecolog. Chem. Eng. 15: $1-27$.

Bosiacki M., Tyksiński W. 2009. Copper, zinc, iron and manganese content in edible parts of some fresh vegetables sold on markets in Poznań. J. Elementol. 14 (1): 13-22. http://dx.doi.org/10.5601/jelem.2009.14.1.02

Brunsgaard G., Kidmose U., Sorensen J.N., Ka ack K., Eggum B.O. 1994. Influence of growth conditions on the value of crisphead lettuce 3 . Protein quality and energy density as determined in balance experiments with rats. Plant Foods Hum. Nutr., 46: 255-265. http://dx.doi.org/10.1007/BF01088998

Daly M.J., Stewart D.P.C. 1999. Influence of „Effective Microorganisms" (EM) on Vegetable Production and Carbon Mineralization - A Preliminary Investigation. J. of Sustain. Agric. 14 (2/3): 15-25. http://dx.doi. org/10.1300/J064v14n02_04

Frąszczak B., Kleiber T., Klama J. 2012. Impact of effective microorganisms on yields and nutrition of sweet basil (Ocimum basilicum L.) and microbiological properties of the substrate Afric. J. Agric. Res. 7(43): 5756-5765.

Górski R., Kleiber T. 2010. Effect of Effective Microorganisms (EM) on nutrient contents in substrate and development and yielding of Rose (Rosa x hybrida) and Gerbera (Gerbera jamesonii). Ecolog. Chem. and Eng. S, 17 (4): 505-513.

Grabińska-Leniowska A. 1999. Laboratory exercises in general microbiology. Eds by the Warsaw Technical University, 233.

Higa T. 1994. Effective microorganisms-A new dimension for nature farming. Proceed. of the 2nd International Nature Farming Conference, (Eds) J.F. Parr et al. USDA; Washington: 20-22.

Higa T. 1996. Effective microorganisms-Their role in Kyusei Nature Farming. Proceed. of the 3rd International Nature Farming Conference, (Eds) J.F. Parr et al. USDA; Washington: 20-23.

Hig a T. 1998. Effective Microorganisms, concept and recent advances in technology. Proceed. of the Conference on Effective Microorganisms for a sustainable agriculture and environment. $4^{\text {th }}$ International Conference on Kyusei Nature Farming, Bellingham - Washington USA: 247-248.

IUNG: 1972. Analytical methods in agricultural-chemistry stations, Part II. Plant analyses. IUNG Puławy: 25-83.

Iw a ish i S. 2000. Effect of Organic Fertilizer and Effective Microorganisms on Growth, Yield and Quality of Paddy-Rice Varieties. J. Crop Production, 3,1 (5): 269-273.

Jarosz Z., Dzida K. 2006. Effect of different nitrogen-potassium fertilization on the yielding and chemical composition of lettuce. Acta Agrophys. 7(3): 591-597.
Karimaei M.S., Massiha S., Mogaddam M. 2004. Comparison of two nutrient solutions effect on growth and nutrient levels of lettuce (Lactuca sativa L.) cultivars. Acta Hort. 644: 69-74.

Kirkby E.A., Pilbeam D.J. 1984. Calcium as a plant nutrient. Plant Cell Environ. 7: 397-405. http://dx.doi. org/10.1111/j.1365-3040.1984.tb01429.x

Kleiber T., Komosa A. 2010. Guide values for anthurium (Anthurium cultorum Birdsey) grown in expanded clay. J. Plant Nutr. 33: 1506-1518.

Kleiber T., Komosa A., Krzyszkowska J., Moliński K. 2009. Seasonal changes in the nutritional status and yielding of Anthurium cultorum Birdsey. Part I. Macroelements. Folia Hort. 21(1): 81-93.

Kobryń J. 1989. The effect of autumn-winter light conditions in glasshouse on the growth and the cropping-cycle of butterhead and Iceberg lettuces. Folia Hort. I/2: 17-25.

Kourtev P.S., Ehrenfeld J.G., Haggblom M. 2002. Exotic plant species alter the microbial community structure and function in the soil. Ecol. 83: 31523166. http://dx.doi.org/10.2307/3071850

Kowalska I., Sady W., Szura A. 2006. Effects of nitrogen form, foliar nutrition and growing place on yield and quality of lettuce. Acta Agrophys. 7(3): 619-631.

Kozik E., Ruprik, B. 2000. Chemical composition of lettuce grown in different substrates with increasing nitrogen fertilization. Anuu. Univ. Agric. Poznan CCCXXIII, 31 (1): 351-355.

Kozik E., Tyksiński W., Komosa, A. 2009. Effect of chelated and mineral forms of micronutrients on their content in leaves and the yield of lettuce. Part III. Zinc. Acta Sci. Pol. Hortorum Cultus, 8 (2): 37-43.

Król J.M. 2006. Azospirillum - asociacing bacteria fixing atmospheric nitrogen. Institute of Cult., Fertiliz. Soil Sci. 14-15.

Kucharski J., Jastrzębska E. 2005. The role of Effective Microorganisms in management of microbiological properties of soil. Ecological Eng. 12: 295-296.

Li Z., Zhang H. 2000. Application of Microbial Fertilizers in sustainable Agriculture. J. Crop Production 3,1 (5): 337-347. http://dx.doi.org/10.1300/J144v03n01_28

Maršić N. K., Osvald J. 2002. Effects of different nitrogen levels on lettuce growth and nitrate accumulation in iceberg lettuce (Lactuca sativa var. capitata L.) grown hydroponically under greenhouse conditions. Gartenbauwissenschaft, 67 (4): 128-134.

Martens D.A., Johanson J.B., Frankenberger W.T. 1992. Production and persistance of soil enzymes with repeated addition of organic residues. Soil Sci. 153: 53-61. http://dx.doi.org/10.1097/00010694-199201000-00008

Martin J.P. 1950. Use of acid, rose Bengal and streptomycin in the plate method for estimating soil fungi. Soil Sci. 69: 215-232. http://dx.doi.org/10.1097/00010694-195 003000-00006 
Myczkowski J., Rożek S., Sady W., Wojtaszek T. 1990. The effect of some factors on the content of nitrate and nitrite in lettuce leaves grown with the nutrient film technique. II. Effect of light and growth regulators in conditions of NPK fertilization discontinued before harvest. Folia Hort. II/1: 7-16.

Ohta H., Hattori T. 1980. Bacteria sensitive to nutrient broth medium in terrestrial environments. Soil Sci. Plant Natur. 26: 99-107. http://dx.doi.org/10.1080/00380768. 1980.10433216

Paul A.E., Clark F.E. 2000. Microbiology and biochemistry of soil. Maria Curie-Skłodowska University Publish., Lublin. http://dx.doi.org/10.1016/B978-0-08-04 7514-1.50005-6

Pięta D., Patkowska E. 2001. Influence of roots secretions of different cultivated plants on population of bacteria and fungi with particular case pathogenic fungi surviving in soil. Acta Agrobot. 54: 96-106.

Rożek S., Myczkowski J., Sady W., Wojtaszek T. 1989. The effect of some factors on the content of nitrate and nitrite in lettuce leaves grown with the nutrient film technique. I. The effect of light and growth regulators. Folia Hort. I/1: 31-43.

Valverde K., Chang M., Rodríguez-Delfín A. 2009. Effect of the light quality on the nitrate reductase activity in lettuce plants grown in NFT. Acta Hort. 843: 89-96.

Waldrop M.P., Balser T.C., Firestone M.K. 2000. Linking microbial community composition to function in tropical soil. Soil Biol. Biochem. 32: 18371846. http://dx.doi.org/10.1016/S0038-0717(00)00157-7

Wielgosz E. 1999. Microbiological and enzymatic activity in brown soil under the cultivation of Sida hermaphrodita and Helianthus tuberosus. Ann. UMCS, 35/36: 173-178.

\section{Wpływ składu chemicznego pożywki, Efektywnych Mikroorganizmów (EM-A) i doświetlania asymilacyjnego roślin na indukowanie wzrostu sałaty (Lactuca sativa $\mathbf{L}$.) w uprawie hydroponicznej}

\section{Streszczenie}

Celem przeprowadzonych badań była ocena wpływu składu chemicznego pożywki (NS I, NS II), inokulacji nasion efektywnymi mikroorganizmami (EM) i doświetlania asymilacyjnego roślin (IA) na wzrost, rozwój i stan odżywienia sałaty (Lactuca sativa $L$.) w uprawie hydroponicznej i zmiany stanu mikrobiologicznego podłoża. Pomiarom podlegały: liczba liści na roślinie (LQ), powierzchnia największych liści na roślinach (SBL), względna zawartość chlorofilu (SPAD), całkowita świeża masa (TFW), całkowita sucha masa (TDW), \% suchej masy, skład chemiczny liści oraz pobranie składników pokarmowych (N, P, K, Ca, Mg, Na) przez części nadziemne roślin. Wykazano wpływ inokulacji nasion EM-A, przy jednoczesnym stosowaniu pożywki II na poprawę dynamiki kiełkowania nasion (1.-5. dzień po wysiewie), ale od 5 do 9 dnia stwierdzono istotny wpływ pożywki I na kiełkowanie nasion. Aplikowanie pożywki II i EM-A pozytywnie wpływało na wytwarzanie liści na roślinie. Stwierdzono istotny wpływ składu chemicznego pożywki na parametry biometryczne roślin. Stosowanie doświetlania asymilacyjnego w uprawie sałaty pozytywnie oddziaływało zarówno na wzrost jak i na rozwój roślin. Skład chemiczny pożywki istotnie modyfikował stan odżywienia roślin makroskładnikami, a doświetlanie roślin tylko w przypadku fosforu - przy jednoczesnym istotnym wpływie na pobranie wszystkich badanych składników przez rośliny. Wpływu EM nie udowodniono. Analiza mikrobiologiczna wykazała istotny wpływ składu chemicznego pożywek na zmiany liczebności analizowanych grup mikroorganizmów, wskazując na wzrost ich liczebności w pożywkach o większej zawartości składników chemicznych. Jakkolwiek nie wykazano istotnych zmian w liczebności mikroorganizmów w zależności od doświetlania asymilacyjnego oraz od inokulacji nasion roztworem EM. 
